\title{
Erratum to: A Pediatric Bone Mass Scan Has Poor Ability to Predict Adult Bone Mass: A 28-Year Prospective Study in 214 Children
}

\section{Christian Buttazzoni • Bjorn E. Rosengren •}

Magnus Tveit • Lennart Landin · Jan-Åke Nilsson •

Magnus K. Karlsson

Published online: 22 January 2014

(C) Springer Science+Business Media New York 2014

Erratum to: Calcif Tissue Int

DOI 10.1007/s00223-013-9802-y

The cells in the Table 1 were shifted from its original form in the original publication. The corrected Table 1 is presented in this erratum.

The online version of the original article can be found under doi:10.1007/s00223-013-9802-y.

C. Buttazzoni $(\bowtie) \cdot$ B. E. Rosengren · M. Tveit · L. Landin Jan-Åke Nilsson · M. K. Karlsson

Clinical and Molecular Osteoporosis Research Unit, Department of Clinical Sciences and Orthopedics, Skåne University Hospital, Lund University, 20502 Malmö, Sweden

e-mail: christian.buttazzoni@med.lu.se 
Table 1 Age, anthropometry, BMI, distal forearm BMC, BMD and bone width in 120 boys and 94 girls with a mean age of 10.3 years (range $3-17$ ) at baseline and mean 28 years (range 25-29) later at a mean age of 37 years (range 28-44)

\begin{tabular}{|c|c|c|c|c|}
\hline & \multicolumn{4}{|l|}{ Cases } \\
\hline & \multicolumn{2}{|c|}{ Women $(n=94)$} & \multicolumn{2}{|c|}{$\operatorname{Men}(n=120)$} \\
\hline & Baseline & Follow-up & Baseline & Follow-up \\
\hline Age (year) & $10.7 \pm 3.9$ & $37.4 \pm 4.1$ & $9.9 \pm 4.0$ & $36.6 \pm 4.0$ \\
\hline Height $(\mathrm{cm})$ & $142.4 \pm 20.3$ & $166.7 \pm 6.4$ & $140.3 \pm 23.5$ & $179.4 \pm 7.6$ \\
\hline Weight (kg) & $37.0 \pm 13.9$ & $72.7 \pm 15.9$ & $35.7 \pm 17.4$ & $86.3 \pm 14.3$ \\
\hline BMI $\left(\mathrm{kg} / \mathrm{m}^{2}\right)$ & $17.4 \pm 2.5$ & $26.1 \pm 5.3$ & $17.2 \pm 3.0$ & $26.8 \pm 4.0$ \\
\hline $\mathrm{BMC}(\mathrm{g} / \mathrm{cm})$ & $0.47 \pm 0.2$ & $0.72 \pm 0.1$ & $0.47 \pm 0.2$ & $1.03 \pm 0.1$ \\
\hline $\operatorname{BMD}\left(\mathrm{g} / \mathrm{cm}^{2}\right)$ & $0.42 \pm 0.1$ & $0.54 \pm 0.1$ & $0.42 \pm 0.1$ & $0.67 \pm 0.1$ \\
\hline Bone width $(\mathrm{cm})$ & $2.1 \pm 0.31$ & $2.65 \pm 0.24$ & $2.17 \pm 0.4$ & $3.09 \pm 0.23$ \\
\hline Age at menarche (years) & $12.7 \pm 1.3$ & $12.7 \pm 1.3$ & - & - \\
\hline Smokers $^{\mathrm{a}}(\%)$ & - & 35.1 & - & 33.1 \\
\hline $\operatorname{Alcohol}^{\mathrm{b}}(\%)$ & - & 3.2 & - & 12.5 \\
\hline Chronic disease $^{\mathrm{c}}(n)$ & - & 1 & - & 2 \\
\hline Food intolerance $(n)$ & - & 4 & - & 2 \\
\hline
\end{tabular}

Data are shown as unadjusted means \pm standard deviation (SD), as proportions $(\%)$ or as numbers $(n)$

$B M I$ body mass index, $B M C$ bone mineral content, $B M D$ bone mineral density

${ }^{a}$ Proportion of individuals with a smoke history of at least 5 years

b Proportion of risk consumers of alcoholic beverages as defined by the National Board of Health and Welfare in Sweden ( $>9$ units of alcohol/ week for women and $>14$ units for men)

${ }^{c}$ Number of individuals with chronic disease with medication (men: hypertension and Mb Crohn, a type of inflammatory bowel disease (IBD), resulting in swelling and dysfunction of the intestinal tract; women: hypothyroidism) 